$\begin{array}{lr} & \text { Per Cent. } \\ \text { Vertebræ, } & 1(0.02) \\ \text { Sternum, } & 1(0.02) \\ \text { Both bones of the leg, } & 610(16.7) \\ \text { Both bones of the arm, } & 262(7.02)\end{array}$

Taking classified fractures of all kinds (closed and open), we have a total of 38,246 . Here the order of frequency is as follows:

\begin{tabular}{|c|c|c|}
\hline & & \\
\hline Radius, & 4,631 & $(12.1)$ \\
\hline lerus, & 3,736 & $(9.7)$ \\
\hline s, & 3,204 & (8.6) \\
\hline Femur, & 3,044 & $(8.2)$ \\
\hline Clavicle, & 2,766 & $(7.2)$ \\
\hline la, & 2,406 & (6.3) \\
\hline Metacarpus, & 1,557 & $(4.07)$ \\
\hline Skull, & 1,517 & (3.96) \\
\hline Tibia, & 1,497 & (3. \\
\hline Phalanges (low. ext.), & 1,286 & $(3.36)$ \\
\hline Tarsus, & 1,150 & $(3.06)$ \\
\hline Inf. maxilla, & 758 & $(1.98)$ \\
\hline Ulna, & 694 & (1.84) \\
\hline Patella, & 688 & (1.83) \\
\hline Facial bones, & 657 & (1.71) \\
\hline Carpus, & 647 & (1.69) \\
\hline Vertebræ, & 332 & $(0.86)$ \\
\hline ula, & 259 & $(0.68)$ \\
\hline Pel & 214 & $(0.56)$ \\
\hline arsus, & 195 & $(0.50)$ \\
\hline Phalanges (low ext.), & 147 & $(0$ \\
\hline maxilla, & 80 & 20) \\
\hline ernum, & 41 & $(0.10)$ \\
\hline & 20 & $(0.05)$ \\
\hline Hyoid, & & 002 \\
\hline $\begin{array}{l}\text { Both bon } \\
\text { Both bon }\end{array}$ & $\begin{array}{l}4,512 \\
2,137\end{array}$ & (1 \\
\hline
\end{tabular}

Considering now the number of fractures by regions we have:

\begin{tabular}{|c|c|c|c|}
\hline $\begin{array}{l}\text { Skull, } \\
\text { Face, }\end{array}$ & Head, & 2,174 & $5.6 \%$ \\
\hline $\begin{array}{l}\text { Spine, } \\
\text { Pelvis, } \\
\text { Coccyx, } \\
\text { Ribs, } \\
\text { Sternum, } \\
\text { Scapula, }\end{array}$ & Trunk, & 4,070 & $10.65 \%$ \\
\hline $\begin{array}{l}\text { Clavicle, } \\
\text { Arm, } \\
\text { Forearm, } \\
\text { Hand, }\end{array}$ & Upper Extremities, & 17,484 & $45.5 \%$ \\
\hline $\begin{array}{l}\text { Femur, } \\
\text { Patella, } \\
\text { Leg, } \\
\text { Foot, }\end{array}$ & Lower Extremities, & 13,639 & $\begin{array}{c}35.6 \% \\
.\end{array}$ \\
\hline
\end{tabular}

\section{THE USE AND ABUSE OF INJECTIONS IN ACUTE GONORRHEAL URETHRITIS.}

BY M. R. DINKELSPIEL, M.D., PHILADELPHIA,

Formerly Resident Physician of the Philadelphia Hospital, etc.

THE title of this article has been purposely worded "Acute Gonorrheal Urethritis" to convey the distinction that discharges from the urethra in the male may exist independent of urethral disease, independent of gonorrheal infection, and even independent of organic involvement. By organic disease I have reference to anterior and posterior urethritis, and the various th inflammations of the bladder, prostate gland and seminal vesicles, as distinguished from non- inflammatory varieties as classified so ably under the head of "functional disorders " by Thompson" who describes them as urethrorrhea, prostatorrhea, spermatorrhea, and phosphaturia. Given a case of acute urethral discharge which by the nature of an inflammatory process is found to be organic in character, and which after microscopical examination of the inflammatory discharge is determined as gonorrheal in origin, when should injections be begun, and what should be the character of these injections? By the term "injection" I do not refer to irrigations of the urethral canal, by the physician, which have their distinct place in the treatment of gonorrhea, and especially if carefully carried out according to the method of Valentine; but $I$ have reference to the use of injections on the part of the patient himself, the indiscriminate use of which has been fruitful of many unpleasant consequences.

In the first place I am opposed to the so-called " abortive" methods of treating gonorrhea br means of powerful astringent substances, such as nitrate of silver, although the latter drug has its distinct usefulness in the latter stages of the disease. My chief reason for opposing it in the acute stages of gonorrhea is, that if it is capable of destroying the gonococci, it cannot do so without an overbalancing amount of injury to the urethra in the acute inflammatory stage, and furthermore the patients usually do not present themselves until the gonococci have penetrated to the submucous tissues, and practically beyond the contact of desirable drugs. It has therefore been my custom to withhold injections on the part of the patient until the acute inflammation had subsided and the character of the discharge had changed from a purulent to a muco-purulent character. I have now somewhat modified this restriction, as hereafter described.

Drugs are only adjuncts in the treatment of gonorrhea. Before they are used or prescribed the patient should be impressed with the necessity of rest, the regulation of his habits and diet. the avoidance of alcohol, coffee, tea, and all highly seasoned and spicy food. The bowels must be kept well regulated, and it is absolutely essential that the urine be kept in a bland condition. Absolute cleanliness should be enjoined, and sexual intercourse emphatically interdicted. As a urinary antiseptic I am accustomed to administer urotropin in five-grain doses three or four times daily. The wearing of the suspensory bandage has its distinct advantages as a mechanical support.

It has often occurred to me that there is indicated in acute inflammations of the urethra some drug which by reason of a deposit left upon the mucous membrane would act as a sedative and perhaps as a very mild astringent. The excellent effect produced by large doses of bismuth administered in catarrhal conditions of the stomach and intestines has been the incentive that caused me to institute a similar procedure in gonorrhea. The insolubility of most of the 1 Med. Rec., vol. Ixviii, no. 27, Dec. 30, 1905. 
bismuth salts offered great difficulties, until I had occasion to employ a combination of bismuth subcarbonate and hydroxide in a fine state of sub-division, suspended in water, manufactured under the name of Lac-Bismo, each fluid dram of which contains two and one half grains of the combined salts. An examination under the microscope of this preparation demonstrated the minuteness of its subdivision in suspension as greater than that of any other bismuth preparation examined. It should be used at first diluted one half with distilled water and rapidly increased in strength, only small quantities at a time being used. If the patient carefully follows the directions as to the proper method of injecting, and the injection is not intrusted to him until the instructions have been rigidly impressed, we have in bismuth a most valuable adjunct in two respects. First, as a mechanical cleansing agent in the acute stage, when it will accomplish the removal of considerable pus and epithelial débris. For this purpose I am accustomed to use it in the form of an irrigation by means of a soft rubber catheter, of small calibre, the solution being about $15 \%$ in strength. The second advantage to be derived from this preparation is its soothing effect upon the mucous membrane of the urethra, this effect being no doubt analogous to the effect of bismuth upon the gastric mucous membrane in catarrhal conditions of that structure. In a case of acute gonorrhea, recently under my observation, the pain after urination was much diminished after an injection of a $50 \%$ solution of Lac-Bismo. with marked diminution in the acuity of the gonorrheal process. It should be remembered, however, that the combination of bismuth salts above referred to is most effective when the urine is in a bland condition, that is, not highly acid. A careful examination by means of the urethroscope will show that bismuth will become deposited upon the urethral mucous membrane in precisely the same manner as it does within the stomach and intestines, and that it owes its beneficial effect to its specific value as a mild antiseptic protective and local sedative. If the urine is not too concentrated in acidity bismuth will assist considerably in neutralizing it. In two cases recently coming under my observation the acute pain during micturition was promptly alleviated by injections of one-half ounce of Lac-Bismo slightly diluted with water before urination, while the discharge and swelling correspondingly decreased. The subsequent micturition was only slightly painful without a previous injection of the bismuth solution, showing that the first injection was still manifesting its protective influence; thus, the diminution of the irritating effects of the urine caused either by reason of its acidity or mechanical influence during its propulsion through the urethra must necessarily have an appreciable influence upon the promotion of resolution.

In the case of the bismuth solution I have made an exception regarding injections during the early stage of the disease. While I am satisfied that highly astringent and corrosive substances are contra-indicated I am equally satisfied that a cleansing, mildly antiseptic and mildly astringent solution like Lac-Bismo is indicated for cleansing purposes, for precisely the same reason that would govern the employment of similar solutions in inflammatory conditions elsewhere when characterized by discharge and exudation of destroyed epithelial tissue. If these injections are used before urination their penetration into the posterior urethra is minimized by reason of their extensive dilution from the subsequent urination; and if this urination is not performed until about five minutes after the injection, their effect will be sufficiently long to greatly overcome the pain caused from urination. I would not hesitate to use the bismuth solution in posterior instillations. At the risk of repetition I want to emphasize again the necessity of carefully instructing the patient as to the manner of injecting, and that only a blunt-pointed hardrubber syringe of small capacity should be employed, that the tip of the same should be well lubricated before using, that the injection should be slowly and carefully made, that the solution should be retained from two to three minutes which is especially necessary in a case of bismuth, as any precipitation of the salts resulting within the urethra is a distinct advantage for reasons already indicated.

My preference for a solution containing the subcarbonate of bismuth is due to its value as an antacid, an advantage which far exceeds the subnitrate or subgallate. After the acute stage has subsided but the discharge still remains thin and serous in character I have found it of advantage to combine the sulphate of zinc or hydrastine with the bismuth solution. The formulæ which have proved quite successful in my hands, are as follows:
R Ext. hydrast. (colorless), 'f Z 3 iii Lac-Bismo,
f 5 i Glycerin, Aqụ destillatæ, q. s. f $\overline{3}$ vi
Ry Zine sulphocarb., Lac-Bismo, Glycerin, Aquæ destillatæ
gr. $x$
f $\frac{5}{\text { ii }}$
f 3 ii q. s. f $\bar{z} v i$

Under no circumstances should injections be used when there is swelling, edema, or much sensitiveness of the urethra.

IN view of the devastation caused by the sleeping sickness among the natives of certain districts of the Congo Free State, as well as among Europeans residing there, the king of Belgium has offered a prize of 200,000 francs to any person of any nationality who shall discover a cure for the said sickness, and also an additional sum of 300,000 franes for the purpose of making researches and experiments toward exterminating the plague.-Science. 